\title{
INTEGRATED MULTI-CRITERIA EVALUATION OF HOUSE'S PLAN SHAPE BASED ON THE EDAS AND SWARA METHODS
}

\author{
Birutė JUODAGALVIENE் ${ }^{\mathrm{a}}$, Zenonas TURSKIS ${ }^{\mathrm{b}}$, Jonas ŠAPARAUSKAS ${ }^{\mathrm{b}}$, \\ Audronè ENDRIUKAITYTE் ${ }^{c}$ \\ ${ }^{a}$ Department of Graphical Systems, Faculty of Fundamental Sciences, \\ Vilnius Gediminas Technical University, Sauletekio al. 11, Vilnius LT-10223, Lithuania \\ ${ }^{b}$ Department of Construction Management and Real Estate, Faculty of Civil Engineering, \\ Vilnius Gediminas Technical University, Sauletekio al. 11, Vilnius LT-10223, Lithuania \\ ${ }^{c}$ Department of Reinforced Concrete and Geotechnics, Faculty of Civil Engineering, \\ Vilnius Gediminas Technical University, Sauletekio al. 11, Vilnius LT-10223, Lithuania
}

Received 09 June 2017; accepted 23 June 2017

\begin{abstract}
With this article we strive to create a theoretical valuation model based on multiple criteria mathematical methods by selecting a basic shape of single-family residential house's plan. Most of the researches and analysis discuss the interfaces of architectural shapes of the buildings with sustainability only in the buildings with unique design. Meanwhile, the model comprising a selection of a basic shape of the singlefamily house was not implemented. Our study evaluated the individual parameters associated with selection of the house shape: compactness, safety, material input, variability of premises and spaces. The SWARA (Step-Wise Weight Assessment Ratio Analysis) method is applied in the calculation of the relative importance of the criteria and the EDAS (The Method of Evaluation Based on Distance from Average Solution) method was used to prioritize the alternatives.
\end{abstract}

Keywords: single-family residential house, house's plan shape, sustainability, SWARA, EDAS.

\section{Introduction}

Over the past decade, a growing part of people already can afford themselves to have a single-family house. This is due to people's desire to separate the work area from the private one (Alfa.lt 2010), the desire to be closer to nature and the national governments' strategy in the issues of housing development (Rid et al. 2017). Demand for individual housing is growing rapidly in all countries, including the EU (Eurostat 2014). With development of a loan systems and growth of consumption needs, a growing number of economy-class customers purchase the standard plots, in which they are building (typical) single-family houses with repeatable design. Single-family residential houses are using more and more energy resources, so their sustainability is as important as all the buildings.

In today's extremely fast changing world, the sustainable development became one of the most important factors in defining the quality buildings (Yang et al. 2017), which create a healthy environment for humans and reduce the negative impact on the environment. John Elkington (1997) was one of the first who named the concept of sustainability TLB (Triple bottom line) as a long term perspective of production effects. And already in 2005, the World Summit on Social Development presented and outlined the definition of sustainability as the three anchors of sustainability: social,

Corresponding author:

J. Šaparauskas E-mail: jonas.saparauskas@vgtu.lt 
environmental and economic (Fig. 1) (SP 2014). The three anchors of sustainability fully define the sustainability problem, satisfying the present needs and causing no threat to meeting the opportunities of future needs. In other words, the sustainability is a setting of high living standards for present and future people generations. The construction industry is one of the areas, covering all three anchors of sustainability: social (Kamali, Hewage 2017), economic (Lizana et al. 2016) and environment protection (Holmstedt et al. 2017).

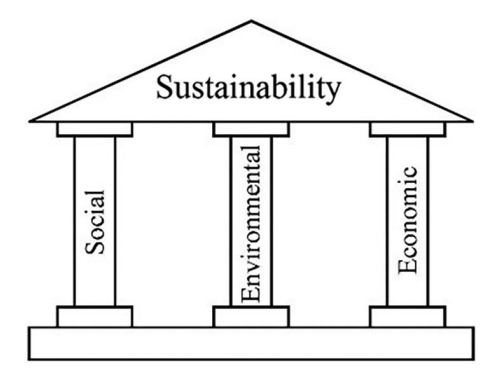

Fig. 1. The Three Pillars of Sustainability (according to SP 2014)

The European Union taking into account the global energy and environmental situation has set a certificate system, regulating the building energy efficiency (Rodriguez-Ubinas et al. 2014). To this end, different countries have developed certification systems, among which the main is BREEM (Building Research Establishment Environmental Assessment Methodology) and LEED (Leadership in Energy and Environmental Design). These and other systems evaluate buildings of the different purpose and/or their environmental and technical aspects (Vilutienè et al. 2015). These methods are not widely used in setting the sustainability of single-family residential houses. Therefore, new systems are being created next to the most famous certification systems, which focus on aspects of the specific type or purpose buildings.

In the scientific literature, interfaces of sustainability of the buildings with spatial shape are examined quite widely, but not much attention is given to the shape of single-family houses. Gou and Xie (2017) in their research have seen the influence of new architectural shapes on sustainability. Caruso and Kampf (2015) with the help of an algorithm intended to increase the use of solar energy, investigated the reduction of energy costs associated with building shapes under the different climatic conditions. Mooneghi and Kargarmoakhar (2016) after the comparison of high-rise and low-rise buildings of older and newer construction have reasoned the interdependence of external shapes and functional space constraints of the buildings. Qi and Wang (2014) have reasoned the use of the shape factor in determining the energy efficiency of the buildings. However, various scientific studies have presented the different conclusions after the evaluation of energy consumption costs in various shapes of the buildings. Some scientific works (Zhang et al. 2016; Jin, Jeong 2014) have presented the reasoning of reduction of the consumed energy costs in comparison with simple and unique shape of the buildings in prejudice of the latter ones. Other scientific works have reasoned the shape interfaces of building types with specific regions of the countries. Krarti and Ihm (2016) have thought that the optimal design of the building, based on the compact solution of architecture can reduce the energy consumption even at $32-60 \%$ in the MENA (Middle East and North Africa) regions. To this end, repeatable designs of the houses created for different climatic regions could solve at least some of the problems associated with energy consumption. Importance of compactness of the panel houses has been denied by the study (Premrov et al. 2016) carried out in three different European cities: Ljubljana, Munich and Helsinki. Average temperature, solar potential, characteristics of unique (free) shape of the buildings (optimum glazing, orientations and so on) has been measured. It was found that climate inclemency has the greatest impact on the energy consumption (it means the annual temperature of the region).

It was found that the shapes of residential buildings influence the sustainability of buildings along with the other parameters after the review of mentioned scientific articles. Soflaei et al. (2017) have identified the additional sustainability criteria of single-family houses: the comfort, privacy and security. And Kang et al. (2014) have evaluated the quality of houses under the psychological, physical, social and even managerial aspects. Bolis et al. (2017) have presented the decisionmaking process model, which is dominated by the importance of individual needs. Therefore, the selection issues of the main constructions and materials of given house, selection of the design of structural elements and the shape of house itself became important. The selection of spatial single-family house's shape is influenced by different restrictions (Micallef et al. 2016), natural conditions, increasing energy consumption requirements, priorities of customers, available resources and other aspects. 
These aforementioned quite complicated decision problems can be effectively solved within multi-criteria decision making (MCDM) framework (Si et al. 2016; Jalaei et al. 2015; Kabak et al. 2014).

Multi-criteria decision-making approach is very useful in many problems such as project selection, supplier selection, risk assessment, contractor evaluation, etc. Many studies have been made on MCDM methods and applications (Ruzgys et al. 2014; Lu et al. 2014; Alimardani et al. 2013).

\section{Problem formulation for the selection of single-family house's plan shape}

This chapter proposes a theoretical shape selection model of the typical single-family house using MCDM system. We assume that the house with a total area of about $150 \mathrm{~m}^{2}$ is made for 2-4 persons of young family, where children age is up to 16 years. We also do not link the selected model shapes with the unique shapes of the building. Basic typical shapes of the single-family houses are chosen for designed buildings (Fig. 2): rectangular, square, L-shaped and cross-shaped. The total area has been evaluated adequately: it was decided that total area of one- and two-story buildings of all kinds is the same. All roofs of single-family houses (alternatives) are pitched, regardless of the number of floors. Stairway area is eliminated from the general area because of the uniformity of total area evaluation.

We should discuss and analyze the criteria relating to assessment of buildings' sustainability and relevance to individual houses while developing a theoretical model of selection of base scheme for the single-family residential house. Typical selection stages are presented in Figure 3.

7 independent experts ( 5 architects and 2 constructors) related to home designing and construction participated in an expert evaluation of shape selection of the typical single-family house. There was no discussion on the importance of the four major criteria. The proposal to include the "aesthetics" criterion was rejected as too subjective. There were selected four major criteria with common expert consensus which have been most relevant in selecting basic shape of typical single-family house. The problem can be solved with MCDM method because it has the structure of several criteria. Experts arranged together the criteria in accordance with importance: material costs of the main structural elements, safety, layout variability of the

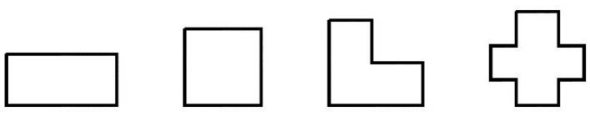

Fig. 2. Basic shapes of single-family house's plan

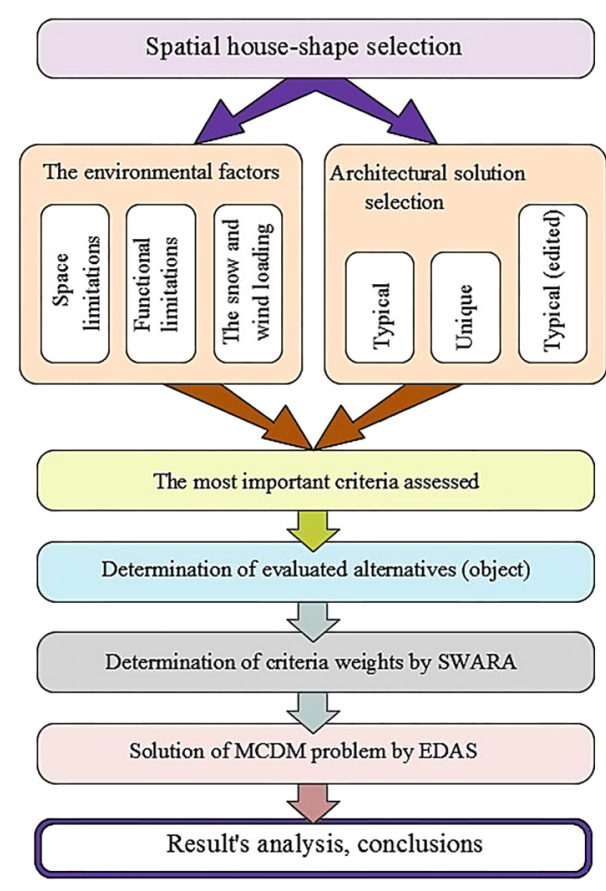

Fig. 3. Spatial house-shape selection scheme

premises and spaces and shape compactness. Criteria and their descriptions sorted by relevance are presented in Table 1.

Costs of materials $\left(c_{1}\right)$ of the structural elements (walls, foundations, spans and roof) are selected because of price relevance. Since the price for economyclass customers is one of the most important aspects, experts gave precedence to this criterion. While comparing a perimeter of square and L-shaped buildings' walls and foundations, the length of the latter ones is bigger by 25 percent. In all cases, the roof area is evaluated only as a two-pitched. It is assumed that the span is constructed only in cases of 2-story houses, and attics in all cases are made warm.

Table 1. Criteria $\left(c_{1}-c_{5}\right)$ sorted by relevance

\begin{tabular}{|c|c|c|}
\hline$c_{1}-c_{5}$ & $\min / \max$ & Criteria titles \\
\hline$c_{1}$ & $\min$ & $\begin{array}{r}\text { Costs of materials of the main } \\
\text { structural elements, } \mathrm{m}^{2}\end{array}$ \\
\hline$c_{2}$ & $\max$ & Safety, scores \\
\hline$c_{3}$ & $\max$ & $\begin{array}{r}\text { Layout variability of the premises } \\
\text { and spaces, scores }\end{array}$ \\
\hline$c_{4}$ & $\max$ & Shape compactness \\
\hline
\end{tabular}


Stairway space in scientific studies is identified as one of the most dangerous spaces of the building (Raina et al. 2015). The analyzed scientific articles focus on the most important aspects of stairway safety this is inclination angle (step width to height ratio) (Asai et al. 2014; Madehkhaksar, Egges 2016; Turskis, Juodagalviene 2016). It is clear that not only sizes of stairs affect the large number of accidents. This is also due to the lack of appropriate attention, behavioral adequacy, people age problems, stairway coverings, lighting and so on. Elder people or children suffer the most severe disasters on the stairs. According to the studies carried out by Startzell et al. in 2000 even $41 \%$ of accidents that occurred on the stairs are related to the lack of attention. Not all opinions of experts were concurring on the importance of safety in assessing the safety criteria $\left(c_{2}\right)$ : most of the designers think that the aesthetic aspect is more important.

Even after selection of a typical project, the customers have their own vision about space zoning issue. The higher the total area of the house, the more space is left for imagination. This layout criterion of premises and spaces $\left(c_{3}\right)$ is relevant when the plot orientation is the poorest in respect of cardinal directions. This is related to the possibilities of the contextuality (in the plot of buildings' zoning).

Criterion of shape compactness $\left(c_{4}\right)$ was selected due to lower energy consumption costs after the review of scientific literature. Energy saving is relevant to both types of buildings: currently designed as well as currently renovated. In all cases, the major percentage of energy savings falls on the rational insulation of exterior partitions and their efficient renewal (Aviža et al. 2015). Authors mentioned in the literature review (Premrov et al. 2016; Krarti, Ihm 2016) have not denied compactness affect on the energy consumption, but they have reasoned more important significance of the other criteria.

\section{Alternatives of the single family residential house}

Factors influencing the designing of single-family residential houses are very different. Therefore, different plots, houses with different designs (unique or typical), structures and materials are selected. However, the main aspects that determine the quality of life in a house are safety and sustainability. Sustainability is determined not only by materials selected according to A or A+ energy efficiency class, but also by other aspects. For example, in unique building case, after the selection of a high house with small area (with second light), it is very hard to reach energy efficiency requirements of class A. After all, energy consumption depends on the area of the house, so in this case, insulation and recuperation system would be too expensive.

A review of typical individual projects presented by Lithuanian architects has been performed before addressing the selection task of the most rational shape for single-family house. Trends of single-family houses shapes have been established after a review of 313 projects created in the last $2-3$ years period (Namu projektai 2017; Namu planai 2017; ekspertai.lt 2017) in Lithuania. The vast majority of typical single-family houses' projects offered by Lithuanian architects are from 80 to $250 \mathrm{~m}^{2}$ of the total area, 1- or 2-story, and their target shape is similar to shapes showed in Figure 2. The review found that $43.5 \%$ houses are of rectangular shape, $18.2 \%$ - of square shape, $16.2 \%$ - Lshaped and $22.1 \%$ - cross-shaped.

We have chosen eight options (Table 2) according to these shapes, i.e. all the shapes presented in Figure 2 for 1 - and 2-storey building cases.

Table 2. Main shapes for single flat dwelling houses

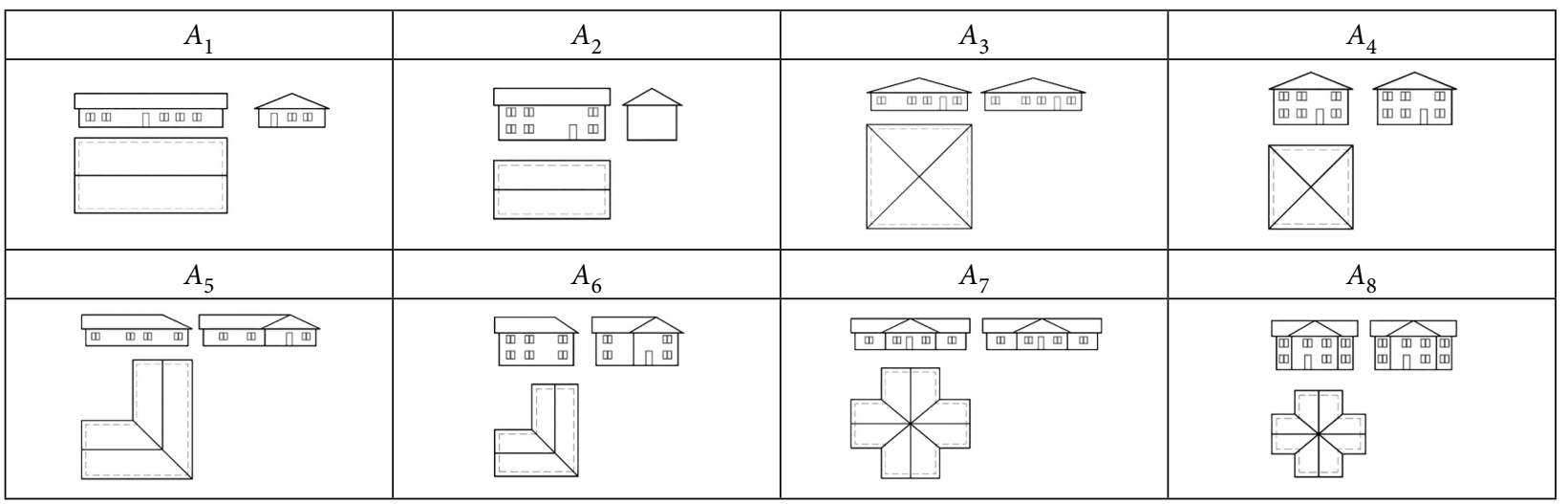




\section{The SWARA method}

In this method (Kersuliene et al. 2010), expert has an important role in evaluations and calculating weights. Also, each expert has chosen the importance of each criterion. Next, each expert ranks all the criteria from the first to the last one (Stanujkic et al. 2015; Nakhaei et al. 2016). An expert uses his or her own implicit knowledge, information and experiences. Based on this method, the most significant criterion is given rank 1 , and the least significant criterion is given rank last. The overall ranks of the group of experts are determined according to the mediocre value of ranks.

The process of determining the relative weights of criteria using SWARA method can accurately be shown by using the following steps:

Step 1. The criteria are sorted in descending order based on their expected significances.

Step 2. Starting from the second criterion, the respondent expresses the relative importance of criterion $j$ in relation to the previous $(j-1)$ criterion, for each particular criterion. According to Kersuliene et al. (2010), this ratio is called the Comparative importance of average value, $s_{j}$ :

$$
s_{j \leftrightarrow j+1}=\frac{\sum_{h=1}^{r} c_{j \leftrightarrow j+1}}{r}, j=\overline{1, n} .
$$

Step 3. Determine the coefficient $k_{j}$ as follows:

$$
k_{j}=s_{j \leftrightarrow j+1}+1, j=\overline{1, n} .
$$

Step 4. Determine the recalculated weight $w_{j}$ as follows:

$$
w_{j}=\frac{w_{j-1}}{k_{j}}, j=\overline{1, n},
$$

Step 5. The relative weights of the evaluation criteria are determined as follows:

$$
q_{j}=\frac{w_{j}}{\sum_{j=1}^{n} w_{j}}, j=\overline{1, n},
$$

where $q_{j}$ denotes the relative weight of criterion $j$.

Table 3 represents results of pairwise comparison made by experts.

Table 4 presents calculation results by SWARA method: the average values of indicators' relative comparative importance, coefficients of indicators' relative comparative importance, converted (intermediate) indicator weights and final indicators' weights.

\section{The EDAS method}

The Evaluation Based on Distance from Average Solution (EDAS) method is introduced by Keshavarz Ghorabaee et al. (2015), and therefore it can be stated as a newly-proposed method. The basic ideas of the EDAS method are the use of two distance measures, namely the Positive Distance from Average (PDA) and the Negative Distance from Average (NDA); and that the evaluation of the alternatives is done according to higher values of the PDA and lower values of the NDA.

Table 3. Relative importance assessment in indicators' pairs

\begin{tabular}{|c|c|c|c|}
\hline \multirow{2}{*}{ Expert } & \multicolumn{3}{|c|}{ Pairwise comparison of criteria relative importance } \\
\cline { 2 - 5 } & $c_{1 \leftrightarrow 2}$ & $c_{2 \leftrightarrow 3}$ & $c_{3 \leftrightarrow 4}$ \\
\hline 1 & 0.3 & 0.6 & 0.2 \\
2 & 0 & 0.8 & 0.4 \\
3 & 0.2 & 0.6 & 0.8 \\
4 & 0.4 & 0.3 & 0.6 \\
6 & 0.1 & 0.7 & 0.5 \\
7 & 0 & 0.8 & 0.1 \\
\end{tabular}

Table 4. Criteria Weighting by SWARA method

\begin{tabular}{|c|c|c|c|c|}
\hline Indicator & $\begin{array}{c}\text { Average values of } \\
\text { comparative importance } \\
\text { indicators, } s_{j \leftrightarrow j+1}\end{array}$ & $\begin{array}{c}\text { Coefficients of comparative } \\
\text { importance indicators, } k_{j}\end{array}$ & $\begin{array}{c}\text { Recalculated } \\
\text { intermediate) indicators } \\
\text { weights, } w_{j}\end{array}$ & $\begin{array}{c}\text { Final indicators } \\
\text { weights, } q_{j}\end{array}$ \\
\hline$c_{1}$ & - & 1.000 & 1.000 & 0.3344 \\
$c_{2}$ & 0.130 & 1.130 & 0.680 & 0.2943 \\
$c_{3}$ & 0.430 & 1.430 & 0.490 & 0.2074 \\
$c_{4}$ & 0.260 & 1.260 & 2.990 & 0.1639 \\
\hline
\end{tabular}


The computational procedure of the EDAS method, for a decision-making problem with $m$ criteria and $n$ alternatives, can be precisely presented as follows.

Step 1. Select the available alternatives, the most important criteria that describe the alternatives, and construct the decision-making matrix $X$, shown as follows:

$$
X=\left[\begin{array}{cccc}
x_{11} & x_{12} & \cdots & x_{1 n} \\
x_{12} & x_{22} & \cdots & x_{2 n} \\
\vdots & \vdots & \vdots & \vdots \\
x_{1 n} & x_{2 n} & \cdots & x_{m n}
\end{array}\right],
$$

where $x_{i j}$ denotes the performance rating of the alternative $i$ on the criterion $j$.

Step 2. Determine the average solution according to all criteria, shown as follows:

$$
x_{j}^{*}=\left(x_{1}, x_{2}, \cdots, x_{n}\right),
$$

where

$$
x_{j}^{*}=\frac{\sum_{i=1}^{m} x_{i j}}{m} .
$$

Step 3. Calculate the positive distance from average $d_{i j}^{+}$and the negative distance from average $d_{i j}^{-}$, according to the type of criteria (benefit and cost), shown as follows:

$$
\begin{gathered}
d_{i j}^{+}= \begin{cases}\frac{\max \left(0,\left(x_{i j}-x_{j}^{*}\right)\right)}{x_{j}^{*}} ; & j \in \Omega_{\max } \\
\frac{\max \left(0,\left(x_{j}^{*}-x_{i j}\right)\right)}{x_{j}^{*}} ; & j \in \Omega_{\min }\end{cases} \\
d_{i j}^{-}= \begin{cases}\frac{\max \left(0,\left(x_{j}^{*}-x_{i j}\right)\right)}{x_{j}^{*}} ; & j \in \Omega_{\max } \\
\frac{\max \left(0,\left(x_{i j}-x_{j}^{*}\right)\right)}{x_{j}^{*}} ; & j \in \Omega_{\min }\end{cases}
\end{gathered}
$$

where $\Omega_{\max }$ and $\Omega_{\min }$ denotes the set of the benefit criteria and the cost criteria, respectively.

Step 4. Determine the weighted sum of PDA, $Q_{i}^{+}$, and the weighted sum of NDS, $Q_{i}^{-}$, for all alternatives, as follows:

$$
\begin{array}{r}
Q_{i}^{+}=\sum_{j=1}^{n} w_{j} d_{i j}^{+} ; \\
Q_{i}^{-}=\sum_{j=1}^{n} w_{j} d_{i j}^{-} .
\end{array}
$$

Step 5. Normalize the values of the weighted sum of the PDA and the weighted sum of the NDA for all alternatives, shown as follows:

$$
\begin{gathered}
S_{i}^{+}=\frac{Q_{i}^{+}}{\max _{i} Q_{i}^{+}} ; \\
S_{i}^{-}=1-\frac{Q_{i}^{-}}{\max _{i} Q_{i}^{-}},
\end{gathered}
$$

where $S_{i}^{+}$and $S_{i}^{-}$denote the normalized weighted sum of the PDA and the NDA, respectively.

Step 6. Calculate the appraisal score $S_{i}$ for all alternatives, as follows:

$$
S_{i}=\frac{1}{2}\left(S_{i}^{+}+S_{i}^{-}\right) .
$$

Step 7. Rank the alternatives according to the decreasing values of appraisal score. The alternative with the highest $S_{i}$ is the best choice among the candidate alternatives.

This paper presents an extension of the EDAS method based on the use of interval grey numbers. On the basis of the proposed extension, the EDAS method can be used most efficiently for solving a larger number of complex real-world decision-making problems, especially those associated with an uncertainty, and so it can be applied in many fields for the purpose of analysis, modeling and forecasting. Finally, the usability and effectiveness of the proposed approach are checked on a known MCDM example. The obtained results confirm the usability of the proposed approach.

In the Table 5 one can find Initial decision making matrix with criteria significance by alternatives.

Calculation process and calculation results by applying EDAS method are presented in Table 6 below.

Table 5. Initial decision making matrix with criteria significance by alternatives

\begin{tabular}{|c|c|c|c|c|c|c|c|c|c|c|c|c|}
\hline & & & Weights & $A_{1}$ & $A_{2}$ & $A_{3}$ & $A_{4}$ & $A_{5}$ & $A_{6}$ & $A_{7}$ & $A_{8}$ & $A^{*}$ \\
\hline$c_{1}$ & $\min$ & $\mathrm{m}^{2}$ & 0.334 & 404.1 & 418.4 & 418.3 & 413.1 & 467.6 & 478.5 & 451.3 & 455.5 & 438.350 \\
\hline$c_{2}$ & $\max$ & scores & 0.294 & 2 & 1 & 2 & 1 & 2 & 1 & 2 & 1 & 1.500 \\
\hline$c_{3}$ & $\max$ & scores & 0.208 & 5 & 6 & 6 & 7 & 5 & 5 & 3 & 4 & 5.125 \\
\hline$c_{4}$ & $\min$ & - & 0.164 & 16 & 6.5 & 17.7 & 6.7 & 20.7 & 7.8 & 19 & 7.3 & 12.713 \\
\hline
\end{tabular}


Table 6. Ranking of alternatives by applying EDAS method

\begin{tabular}{|c|c|c|c|c|c|c|c|c|c|c|}
\hline & \multicolumn{10}{|c|}{$d_{i j}^{+}$} \\
\hline & $A^{*}$ & $A_{1}$ & $A_{2}$ & $A_{3}$ & $A_{4}$ & $A_{5}$ & $A_{6}$ & $A_{7}$ & $A_{8}$ & \\
\hline$c_{1}$ & 438.350 & 0.078 & 0.046 & 0.046 & 0.058 & -0.067 & -0.092 & -0.030 & -0.039 & \\
\hline$c_{2}$ & 1.500 & 0.333 & -0.333 & 0.333 & -0.333 & 0.333 & -0.333 & 0.333 & -0.333 & \\
\hline$c_{3}$ & 5.125 & -0.024 & 0.171 & 0.171 & 0.366 & -0.024 & -0.024 & -0.415 & -0.220 & \\
\hline$c_{4}$ & 12.713 & -0.259 & 0.489 & -0.392 & 0.473 & -0.628 & 0.386 & -0.495 & 0.426 & $\max _{i} Q_{i}^{+}$ \\
\hline \multirow[t]{3}{*}{$Q_{i}^{+}$} & & 0.077 & 0.033 & 0.085 & 0.075 & -0.032 & -0.070 & -0.079 & -0.087 & 0.085 \\
\hline & \multicolumn{10}{|c|}{$d_{i j}^{-}$} \\
\hline & & $A_{1}$ & $A_{2}$ & $A_{3}$ & $A_{4}$ & $A_{5}$ & $A_{6}$ & $A_{7}$ & $A_{8}$ & \\
\hline$c_{1}$ & & -0.078 & -0.046 & -0.046 & -0.058 & 0.067 & 0.092 & 0.030 & 0.039 & \\
\hline$c_{2}$ & & -0.333 & 0.333 & -0.333 & 0.333 & -0.333 & 0.333 & -0.333 & 0.333 & \\
\hline$c_{3}$ & & 0.024 & -0.171 & -0.171 & -0.366 & 0.024 & 0.024 & 0.415 & 0.220 & \\
\hline$c_{4}$ & & 0.259 & -0.489 & 0.392 & -0.473 & 0.628 & -0.386 & 0.495 & -0.426 & $\max _{i} Q_{i}^{-}$ \\
\hline$Q_{i}^{-}$ & & -0.077 & -0.033 & -0.085 & -0.075 & 0.032 & 0.070 & 0.079 & 0.087 & 0.087 \\
\hline$S_{i}^{+}$ & & 0.909 & 0.386 & 1.000 & 0.882 & -0.382 & -0.834 & -0.933 & -1.029 & \\
\hline$S_{i}^{-}$ & & 1.883 & 1.375 & 1.972 & 1.858 & 0.629 & 0.190 & 0.093 & 0.000 & \\
\hline$S_{i}$ & & 1.396 & 0.881 & 1.486 & 1.370 & 0.124 & -0.322 & -0.420 & -0.514 & \\
\hline Rank & & 2 & 4 & 1 & 3 & 5 & 6 & 7 & 8 & \\
\hline
\end{tabular}

\section{Conclusions}

The EDAS calculation method provides the best option: a square shape one-storey house $\left(A_{3}\right)$. Despite a much more compact shape of 2-storey houses, the selection of the best alternatives was determined by a safety factor, i.e. elimination of internal stairway. According to the results obtained, the advantage of the first four options (rectangular and square shapes) is obvious. The results confirmed the suitability of selected shapes of the typical single-family houses' projects created by Lithuanian architects for economy-class customers.

\section{References}

Alfa.lt 2010. Gyvenamoji aplinka ir sveikata [online], [cited 5 July 2016]. Available from Internet: http://www.alfa.lt/straipsnis/10418538/gyvenamoji-aplinka-ir-sveikata

Alimardani, M.; Hashemkhani Zolfani, S.; Aghdaie, M. H.; Tamosaitiene, J. 2013. A novel hybrid SWARA and VIKOR methodology for supplier selection in an agile environment, Technological and Economic Development of Economy 19(3): 533-548. https://doi.org/10.3846/20294913.2013.814606

Asai, T.; Misu, S.; Doi, T.; Yamada, M.; Ando, H. 2014. Effects of dual-tasking on control of trunk movement during gait: respective effect of manual-and cognitive-task, Gait Posture 39: 54-59. https://doi.org/10.1016/j.gaitpost.2013.05.025

Aviža, D.; Turskis, Z.; Kaklauskas, A. 2015. A multiple criteria decision support system for analyzing the correlation be- tween the thickness of a thermo-insulation layer and its payback period of the external wall, Journal of Civil Engineering and Management 21(6): 827-835.

https://doi.org/10.3846/13923730.2015.1046910

Bolis, I.; Morioka, S. N.; Sznelwar, L. I. 2017. Are we making decisions in a sustainable way? A comprehensive literature review about rationalities for sustainable development, Journal of Cleaner Production 145: 310-322.

https://doi.org/10.1016/j.jclepro.2017.01.025

Caruso, G.; Kampf, J. H. 2015. Building shape optimisation to reduce air-conditioning needs using constrained evolutionary algorithms, Solar Energy 118: 186-196.

https://doi.org/10.1016/j.solener.2015.04.046

ekspertai.lt. 2017. Individualiu namu projektai [online], [cited 5 April 2017]. Available from Internet: http://www.ekspertai. lt/individualiu_namu_projektai

Elkington, J. 1997, Cannibals with forks: the triple bottom line of 21st Century business. Capstone.

Eurostat. 2014. Eurostat, statistics explained [online], [cited 5 April 2017]. Available from Internet: http://ec.europa.eu/ eurostat/statistics-explained/index.php/Housing_statistics/lt

Gou, Z.; Xie, X. 2017. Evolving green building: triple bottom line or regenerative design?, Journal of Cleaner Production 153: 600-607. https://doi.org/10.1016/j.jclepro.2016.02.077

Holmstedt, L.; Brandt, N.; Robert, K. H. 2017. Can Stockholm Royal Seaport be part of the puzzle towards global sustainability? - From local to global sustainability using the same set of criteria, Journal of Cleaner Production 140(1): 72-80. https://doi.org/10.1016/j.jclepro.2016.07.019

Jalaei, F.; Jrade, A.; Nassiri, M. 2015. Integrating decision support system (DSS) and building information modeling (BIM) to optimize the selection of sustainable building com- 
ponents, Journal of Information Technology in Construction 20: 399-420.

Jin, J.; Jeong, J. 2014. Optimization of a free-form building shape to minimize external thermal load using genetic algorithm, Energy and Buildings 85: 473-482. https://doi.org/10.1016/j.enbuild.2014.09.080

Kabak, M.; Kose, E.; Kirilmaz, O.; Burmaoglu, S. 2014. A fuzzy multi-criteria decision making approach to assess building energy performance, Energy and Buildings 72: 382-389. https://doi.org/10.1016/j.enbuild.2013.12.059

Kamali, M.; Hewage, K. 2017. Development of performance criteria for sustainability evaluation of modular versus conventional construction methods, Journal of Cleaner Production 142(4): 3592-3606.

https://doi.org/10.1016/j.jclepro.2016.10.108

Kang, N. N.; Kim, J. T.; Lee, T. K. 2014. A Study on the healthy housing quality of multi-family attached house according to dwelling unit age, Energy Procedia 62: 595-602.

https://doi.org/10.1016/j.egypro.2014.12.422

Kersuliene, V.; Zavadskas, E. K.; Turskis, Z. 2010. Selection of rational dispute resolution method by applying new stepwise weight assessment ratio analysis (SWARA), Journal of Business Economics and Management 11(2): 243-258. https://doi.org/10.3846/jbem.2010.12

Keshavarz Ghorabaee, M.; Zavadskas, E. K.; Olfat, L.; Turskis, Z. 2015. Multi-criteria inventory classification using a new method of Evaluation Based on Distance from Average Solution (EDAS), Informatica 26(3): 435-451. https://doi.org/10.15388/Informatica.2015.57

Krarti, M.; Ihm, P. 2016. Evaluation of net-zero energy residential buildings in the MENA region, Sustainable Cities and Society 22: 116-125. https://doi.org/10.1016/j.scs.2016.02.007

Lizana, J.; Barrios-Padura, A.; Molina-Huelva, M.; Chacartegui, R. 2016. Multi-criteria assessment for the effective decision management in residential energy retrofitting, Energy and Buildings 129: 284-307.

https://doi.org/10.1016/j.enbuild.2016.07.043

Lu, S. T.; Yu, S. H.; Chang, D. S. 2014. Using fuzzy multiple criteria decision-making approach for assessing the risk of railway reconstruction project in Taiwan, The Scientific World Journal 2014: 239793. http://dx.doi.org/10.1155/2014/239793

Madehkhaksar, F.; Egges, A. 2016. Effect of dual task type on gait and dynamic stability during stair negotiation at different inclinations, Gait \& Posture 43: 114-119. https://doi.org/10.1016/j.enbuild.2016.07.043

Micallef, D.; Buhagiar, V.; Borg, S. P. 2016. Cross-ventilation of a room in a courtyard building, Energy and Buildings 133: 658-669. https://doi.org/10.1016/j.enbuild.2016.09.053

Mooneghi, M. A.; Kargarmoakhar, R. 2016. Aerodynamic mitigation and shape optimization of buildings: review, Journal of Building Engineering 6: 225-235. https://doi.org/10.1016/j.jobe.2016.01.009

Nakhaei, J.; Bitarafan, M.; Arefi, S. L.; Kaplinski, O. 2016. Model for rapid assessment of vulnerability of office buildings to blast using SWARA and SMART methods (a case study of Swiss re tower), Journal of Civil Engineering and Management 22(6): 831-843. https://doi.org/10.3846/13923730.2016.1189457

Namu planai. 2017 [online], [cited 5 April 2017]. Available from Internet: http://www.namuplanai.lt/
Namu projektai. 2017 [online], [cited 5 April 2017]. Available from Internet: http://lt.lt.allconstructions.com/portal/categories/459/namu-projektai

Premrov, M.; Leskovar, V. Z.; Mihalic, K. 2016. Influence of the building shape on the energy performance of timber-glass buildings in different climatic conditions, Energy 108(1): 201-211. https://doi.org/10.1016/j.energy.2015.05.027

Qi, F.; Wang, Y. 2014. A new calculation method for shape coefficient of residential building using Google Earth, Energy and Buildings 76: 72-80. https://doi.org/10.1016/j.enbuild.2014.02.058

Raina, P.; Sohel, N.; Oremus, M.; Shannon, H.; Mony, P.; Kumar, R.; Li, W.; Wang, Y.; Wang, X.; Yusoff, K.; Yusuf, R.; Iqbal, R.; Szuba, A.; Oguz, A.; Rosengren, A.; Kruger, A.; Chifamba, J.; Mohammadifard, N.; Darwish, E. A.; Dagenais, G.; Diaz, R.; Avezum, A.; Lopez-Jaramillo, P.; Seron, P.; Rangarajan, S.; Teo, K.; Yusuf, S. 2015. Assessing global risk factors for non-fatal injuries from road traffic accidents and falls in adults aged 35-70 years in 17 countries: a cross-sectional analysis of the Prospective Urban Rural Epidemiological (PURE) study, US National Library of Medicine National Institutes of Health 17.

https://doi.org/10.1136/injuryprev-2014-041476

Rid, W.; Lammers, J.; Zimmermann, S. 2017. Analysing sustainability certification systems in the German housing sector from a theory of social institutions, Ecological Indicators 76: 97-110. https://doi.org/10.1016/j.ecolind.2016.12.022

Rodriguez-Ubinas, E.; Rodriguez, S.; Voss, K.; Todorovic, M. S. 2014. Energy efficiency evaluation of zero energy houses, Energy and Buildings 83: 23-35.

https://doi.org/10.1016/j.enbuild.2014.06.019

Ruzgys, A.; Volvaciovas, R.; Ignatavicius, C.; Turskis, Z. 2014. Integrated evaluation of external wall insulation in residential buildings using SWARA-TODIM MCDM method, Journal of Civil Engineering and Management 20(1): 103-110. https://doi.org/10.3846/13923730.2013.843585

Si, J.; Marjanovic-Halburd, L.; Nasiri, F.; Bell, S. 2016. Assessment of building-integrated green technologies: a review and case study on applications of Multi-Criteria Decision Making (MCDM) method, Sustainable Cities and Society 27: 106-115. https://doi.org/10.1016/j.scs.2016.06.013

Soflaei, F.; Shokouhian, M.; Zhu, W. 2017. Socio-environmental sustainability in traditional courtyard houses of Iran and China, Renewable and Sustainable Energy Reviews 69: 11471169. https://doi.org/10.1016/j.rser.2016.09.130

SP. 2014. Sustainability problem [online], [cited 23 January 2016]. Available from Internet: http://www.thwink.org/sustain/glossary/Sustainability.htm

Stanujkic, D.; Karabasevic, D.; Zavadskas, E. K. 2015. A framework for the selection of a packaging design based on the SWARA method, Inzinerine Ekonomika-Engineering Economics 26(2): 181-187. https://doi.org/10.5755/j01.ee.26.2.8820

Startzell, J. K.; Owens, D. A.; Mulfinger, L. M. 2000. Stair negotiation in older people: a review, Journal American Geriatrics Society 48(5): 567-580. https://doi.org/10.1111/j.1532-5415.2000.tb05006.x

Turskis, Z.; Juodagalvienė, B. 2016. A novel hybrid multi-criteria decision-making model to assess a stairs shape for dwelling houses, Journal of Civil Engineering and Management 22(8): 1055-1065. https://doi.org/10.3846/13923730.2016.1259179 
Vilutienè, T.; Migilinskas, D.; Bružas, A. 2015. Holistic approach to assess the sustainability and utility of refurbishment measure, Procedia Engineering 122: 137-142. https://doi.org/10.1016/j.proeng.2015.10.017

Yang, M.; Lin, M.; Lin, Y.; Tsai, K. 2017. Multiobjective optimization design of green building envelope material using a non-dominated sorting genetic algorithm, Applied Thermal Engineering 111: 1255-1264.

https://doi.org/10.1016/j.applthermaleng.2016.01.015
Zhang, L,; Xu, Y.; Yeh, C.; Liu, Y.; Zhou, D. 2016. City sustainability evaluation using multi-criteria decision making with objective weights of interdependent criteria, Journal of Cleaner Production 131: 491-499. https://doi.org/10.1016/j.jclepro.2016.04.153

Birutė JUODAGALVIENĖ. Lecturer at the Department of Graphical Systems, Vilnius Gediminas Technical University (VGTU), Faculty of Fundamental Sciences, Lithuania. Research interests: engineering graphics in building design, building design, information technologies.

Zenonas TURSKIS. Professor at Department of Construction Management and Real Estate at Vilnius Gediminas Technical University, Lithuania. His research interests include building technology and management, decision-making theory, computer-aided automation in design and expert systems. He is the author of more than 100 research papers, which are referred in WoS database.

Jonas ŠAPARAUSKAS. Doctor, Associate Professor. Department of Construction Management and Real Estate. Vilnius Gediminas Technical University, Lithuania. Member of EURO Working Group OR in Sustainable Development and Civil Engineering (EWG-ORSDCE). He has published over 50 publications. Research interests: construction technology and organisation, project management, quality management, multiple criteria decision making, sustainable development.

Audronė ENDRIUKAITYTE். Dr, Marketing Director at private company Paroc UAB, a lecturer at the Department of Reinforced Concrete and Geotechnics, Vilnius Gediminas Technical University, Lithuania. Her research interests include building structures and thermal processes in buildings. 